\title{
EFFECTS OF BETAINE-RICH NANO FERTILIZER ON IMPROVING PHYSIOLOGY OF Zea mays var. saccharata AND Arabidopsis thaliana UNDER SALT STRESS
}

\author{
FADZIL SUHAIMI FADZILLAH ADIBAH, MD SARWAR JAHAN, \\ HASAN NUDIN NUR FATIHAH*, NADIAWATI ALIAS and \\ MOHAMMAD MONERUZZAMAN KHANDAKER \\ School of Agriculture Science and Biotechnology, Faculty of Bioresources and Food Industry, \\ Universiti Sultan Zainal Abidin (UniSZA), Besut Campus, \\ 22200 Besut, Terengganu, Malaysia \\ *E-mail: fatihah@unisza.edu.my
}

Accepted 6 October 2020, Published online 25 December 2020

\begin{abstract}
Salinity is the second major obstacle after drought conditions that hinder the high productivity of plants. Many factors contribute to the salinity problem, consequently affects the plant physiology, growth as well as production. Therefore, this research aims to determine the effects of betaine-rich Nano fertilizer on physiological parameters of sweet corn (Z. mays var. saccharata) and $A$. thaliana under salt stress. In this study, plants were grown in a controlled plant growth room. Five salinity levels (S0:0 dS/m, S1:2 dS/m, S2:4 dS/m, S3:6 dS/m, and S4:8 dS/m), two concentrations of betaine (B0:0 mM and B1: $50 \mathrm{mM}$ ) and the application of Nano fertilizer (N0: without Nano fertilizer and N1: with Nano fertilizer) were tested in Randomized Complete Block Design (RCBD) with three replicates. Data for chlorophyll content, chlorophyll fluorescence $\left(\mathrm{F}_{\mathrm{V}} / \mathrm{F}_{\mathrm{M}}\right)$, and leaf relative water content (RWC) were recorded. The results were analyzed using a two-way analysis of variance (ANOVA) followed by the Duncan posthoc test. Sweet corn and A. thaliana under salt stress showed a significant increase in chlorophyll content and leaf RWC, but not in $\mathrm{F}_{\mathrm{V}} / \mathrm{F}_{\mathrm{M}}$. Therefore, it is anticipated that betaine-rich Nano fertilizer could reduce salt stress by improving the physiological parameters in sweet corn as well as in A. thaliana.
\end{abstract}

Key words: Betaine-rich Nano fertilizer, salt stress, Z. mays var. saccharata, A. thaliana, physiology

\section{INTRODUCTION}

Saline soil refers to the soil that contains excessive soluble salts like sodium, calcium, magnesium, sulphate, and chloride (Butcher et al., 2016). More than $20 \%$ and $50 \%$ of agriculture and irrigated land are saline areas, respectively (Habib et al., 2016). Saline soil influences water extraction by plants. This condition increases reactive oxygen species (ROS) like hydrogen peroxide $\left(\mathrm{H}_{2} \mathrm{O}_{2}\right)$, superoxide ion $\left(\mathrm{O}_{2^{-}}\right)$, hydroxyl radical $(\mathrm{OH})$, and hydroxyl ion $\left(\mathrm{OH}^{-}\right)$in the plant cell, leads to the closure of stomata and reduces the water loss. In a long term, this condition decreases plant water availability, creates osmotic stress which can cause damage to the plant cell (Liang et al., 2018). Hence, salt stress restricted plant growth and productivity subsequently

\footnotetext{
* To whom correspondence should be addressed.
}

increased the demand for food (Machado \& Serralheiro, 2017).

Betaine is the trimethyl derivative of glycine, an amphoteric quartery amine, that acts as organic osmolytes to withstand different extreme environmental conditions such as UV radiation, heavy metals, drought, salinity, heat, and cold (Day \& Kempson, 2016). Some of the researchers used the term glycine betaine to differentiate it from other betaine derivatives like proline betaine and alanine betaine (Tian et al., 2017). Betaine acts in two ways; first acting as a nontoxic cytoplasmic osmolyte to raise osmotic pressure, second, to stabilizes enzymes and membranes against damage by salt stress (Tian et al., 2017).

Nowadays, the application of fertilizers and unsafe pesticides has led to environmental pollution such as eutrophication, groundwater pollution, air pollution, and poor soil quality (Chen et al., 2018). Therefore, the existence of Nanotechnology has 
developed fertilizers in Nano size and shape which provide site-specific for the active ingredients to be released gradually to the plants and soils (Chhipa et al., 2017; León-Silva et al., 2018). As a result, the loss of fertilizer can be controlled and the absorption of nutrients by plant and soil can be increased efficiently (El-Ramady et al., 2018). Then, agriculture production can be sustained.

Zea mays L. var. saccharata or sweet corn stores more sugar than field corn due to naturally occurring genetic mutation. Currently, it becomes the most important crop in the world for cereals production and provides raw materials for industry (Siyuan et al., 2018). People consumed sweet corn habitually due to their nutritional values like minerals, phytochemicals properties, and dietary fiber (Siyuan et al., 2018). Arabidopsis thaliana (L.) Heynh. is a model plant used in scientific researches such as for plant physiology and biochemistry studies. Both sweet corn and A. thaliana are categorized as a saltsensitive plant which is known as glycophytes (Joshi et al., 2015).

Previous reports have demonstrated the role of betaine in reducing salt stress and the effects of Nano fertilizer on the physiology of plants such as Ocimum basilicum L. (Alipour et al., 2016), Allium cepa L. (Rady et al., 2018), and Brassica napus L. (Hezaveh et al., 2019). However, the effect of both betaine and Nano fertilizer to overcome salt stress remains to be examined. In this study, we showed the effects of betaine-rich Nano fertilizer on the physiology of $Z$. mays var. saccharata and $A$. thaliana under saline conditions and the interactions between salinity and betaine-rich Nano fertilizer on the plant physiology.

\section{MATERIALS AND METHODS}

\section{Plant materials and treatments}

Five levels of salinity (S0; $0 \mathrm{dS} / \mathrm{m}, \mathrm{S} 1 ; 2 \mathrm{dS} / \mathrm{m}$, $\mathrm{S} 2 ; 4 \mathrm{dS} / \mathrm{m}, \mathrm{S} 3 ; 6 \mathrm{dS} / \mathrm{m}$, and $\mathrm{S} 4 ; 8 \mathrm{dS} / \mathrm{m})$, two different concentrations of betaine [B0;0 mM (without betaine) and $\mathrm{B} 1 ; 50 \mathrm{mM}$ (with betaine)] and with $(\mathrm{N} 1 ; 3 \mathrm{~mL} / \mathrm{L})$ and without Nano fertilizer (N0; $0 \mathrm{~mL} / \mathrm{L}$ ) were used based on the treatments combination (B0N0, B1N0, B0N1 and B1N1). Then, the treatments were arranged as a Randomized Complete Block Design (RCBD) with three replications. The betaine-rich Nano fertilizer consists of salt $(\mathrm{NaCl})$ (Bendosen, Malaysia), betaine (SigmaAldrich, Finland), inorganic fertilizer (Vitagrow, Malaysia), and Nano fertilizer (New Suryamin, India). The treatments were applied two times after sowing.

The seed of sweet corn (Narm Tao, Thailand) and $A$. thaliana (Ohio State University, Columbus) were used in this study. The growing media of sweet corn consisted of sandy soils and peat moss in ratio $3: 1$. For $A$. thaliana, the growing media consisted of vermiculite and peat moss in ratio $3: 1$. The growing media were mixed well before being filled into the individual pot $(11 \mathrm{~cm}$ in diameter) for sweet corn and araflat $(6 \mathrm{~cm}$ in diameter) for A. thaliana. Nano fertilizer $(3 \mathrm{~mL} / \mathrm{L})$, inorganic fertilizer $(5 \mathrm{~mL} / \mathrm{L}$ for sweet corn and $3 \mathrm{~mL} / \mathrm{L}$ for A. thaliana), $\mathrm{NaCl}[2 \mathrm{dS} / \mathrm{m}(675 \mathrm{mg} / \mathrm{L}), 4 \mathrm{dS} / \mathrm{m}$ $(1350 \mathrm{mg} / \mathrm{L}), 6 \mathrm{dS} / \mathrm{m}(2025 \mathrm{mg} / \mathrm{L})$ and $8 \mathrm{dS} / \mathrm{m}(2700$ $\mathrm{mg} / \mathrm{L})$ ] and betaine [stock solution $(500 \mathrm{mM})$, working solution $(50 \mathrm{mM})]$ were prepared in solution form using distilled water. Pots and araflat were labeled according to the RCBD. After that, seeds were sown followed by the application of treatments. For sweet corn, betaine and Nano fertilizer were poured onto the soil, while for $A$. thaliana, betaine and Nano fertilizer were applied by the foliar method. The methods of application were different due to the different apparatus used to grow the plants. Plants were grown in a controlled growth room under a photoperiod of $16 \mathrm{hr}$ of light and eight hr of the dark cycle, temperature $(22 \pm$ $\left.2{ }^{\circ} \mathrm{C}\right)$, and relative humidity $(60 \pm 10 \%)$. The second treatment was applied in the second week and third week for sweet corn and $A$. thaliana, respectively. Data for physiological parameters were recorded started from 17 days after sowing for sweet corn and 27 days after sowing for A. thaliana.

\section{Measurement of chlorophyll content and chlorophyll fluorescence $\left(\mathbf{F}_{\mathbf{V}} / \mathbf{F}_{\mathbf{M}}\right)$ \\ Chlorophyll content was measured by using SPAD-502plus portable chlorophyll meter (Konica Minolta, Japan) according to Rady et al. (2018). JUNIORPAM chlorophyll fluorometer (Walz, Germany) was used to record chlorophyll fluorescence $\left[\mathrm{F}_{\mathrm{V}} / \mathrm{F}_{\mathrm{M}}\right.$ (maximal quantum efficiency of PS II)].}

\section{Determination of leaf relative water content (RWC) \\ Fresh leaf was detached from the plant then} immediately weighed by using analytical balance to determine the fresh weight (FW). Then, the leaf was soaked in a Petri dish containing distilled water for $24 \mathrm{hr}$ to determine the turgid weight (TW). Before weigh, excess water was removed by using tissue paper. Next, the leaf was kept in a universal oven (Memmert) at $60^{\circ} \mathrm{C}$ for $24 \mathrm{hr}$ then weighed to get dry weight (DW). The leaf RWC was calculated based on the formula (Syuhada \& Jahan, 2016):

$$
\mathrm{RWC}(\%)=[(\mathrm{FW}-\mathrm{DW}) /(\mathrm{TW}-\mathrm{DW})] \times 100
$$

\section{Statistical analysis}

Data were subjected to two-way analysis of variance (ANOVA) using Statistical Package for Social Science (SPSS) version 23. Means were 
separated by Duncan post-hoc test and the differences were considered as statistically significant when $p<0.05$.

\section{RESULTS}

Effects of betaine-rich Nano fertilizer on chlorophyll content of sweet corn and $\boldsymbol{A}$. thaliana

SPAD-502plus portable chlorophyll meter (Konica Minolta, Japan) was used to measure chlorophyll content of sweet corn and A. thaliana under different salinity levels $(0,2,4,6$ and $8 \mathrm{dS} / \mathrm{m})$ and treatments [without betaine and Nano fertilizer (B0N0), with a single application of betaine (B1N0), with a single application of Nano fertilizer (B0N1) and a combination of betaine-rich Nano fertilizer (B1N1)] and a control (B0N0) at $0 \mathrm{dS} / \mathrm{m}$. A statistically significant interaction between salinity levels and betaine-rich Nano fertilizer on chlorophyll content of sweet corn and $A$. thaliana $(p<0.0005)$ was found.

Figure 1A proved that the chlorophyll content of sweet corn treated with B0N0 was significantly declined under saline conditions. In contrast, B1N1 was significantly increased under saline conditions. B1N1 at $0 \mathrm{dS} / \mathrm{m}(41.27 \mathrm{~nm})$ and $8 \mathrm{dS} / \mathrm{m}$ (41.07 nm) were significantly increased compared to the control (39.57 nm). However, B1N1 at $2 \mathrm{dS} / \mathrm{m}$ (40.13 nm) showed no significant difference, while B1N1 at 4 $\mathrm{dS} / \mathrm{m}(37.37 \mathrm{~nm})$ and $6 \mathrm{dS} / \mathrm{m}(37.87 \mathrm{~nm})$ were significantly decreased compared to the control $(39.57 \mathrm{~nm})$.

Chlorophyll content of $A$. thaliana treated with B1N1 was significantly elevated compared to B0N0 (Figure 1B). Moreover, B1N1 at $0 \mathrm{dS} / \mathrm{m}(28.63 \mathrm{~nm})$, $2 \mathrm{dS} / \mathrm{m}(26.53 \mathrm{~nm}), 4 \mathrm{dS} / \mathrm{m}(26.10 \mathrm{~nm}), 6 \mathrm{dS} / \mathrm{m}$
$(28.37 \mathrm{~nm})$ and $8 \mathrm{dS} / \mathrm{m}(24.87 \mathrm{~nm})$ were significantly higher from the control $(21.53 \mathrm{~nm})$. B1N1 at $0 \mathrm{dS} /$ $\mathrm{m}$ was significantly increased from $\mathrm{B} 1 \mathrm{~N} 1$ at 2,4 , and $8 \mathrm{dS} / \mathrm{m}$, nonetheless, it was comparable to B1N1 at $6 \mathrm{dS} / \mathrm{m}$.

Effects of betaine-rich Nano fertilizer on chlorophyll fluorescence $\left(\mathrm{F}_{\mathrm{V}} / \mathrm{F}_{\mathrm{M}}\right)$ of sweet corn and A. thaliana

No significant interaction between salinity levels and betaine-rich Nano fertilizer was observed on $\mathrm{F}_{\mathrm{V}} / \mathrm{F}_{\mathrm{M}}$ of sweet corn $(p=0.984)$ and $A$. thaliana $(p=0.997)$. The $\mathrm{F}_{\mathrm{V}} / \mathrm{F}_{\mathrm{M}}$ of sweet corn treated with B0N0 started to decrease from $2 \mathrm{dS} / \mathrm{m}$ to $8 \mathrm{dS} / \mathrm{m}$ under saline conditions, whereas $\mathrm{B} 1 \mathrm{~N} 1$ has fluctuated under saline conditions (Figure 2A). At all salinity levels, no significant difference was found between $\mathrm{B} 1 \mathrm{~N} 1$ and control, but $\mathrm{B} 1 \mathrm{~N} 1$ at 0 $\mathrm{dS} / \mathrm{m}$ (0.81), $2 \mathrm{dS} / \mathrm{m}$ (0.82), $4 \mathrm{dS} / \mathrm{m}$ (0.72) and 6 $\mathrm{dS} / \mathrm{m}(0.80)$ were escalated from the control (0.71). However, B1N1 at $8 \mathrm{dS} / \mathrm{m}(0.71)$ was found to be similar to the control (0.71).

Figure $2 \mathrm{~B}$ showed that $\mathrm{F}_{\mathrm{V}} / \mathrm{F}_{\mathrm{M}}$ of $A$. thaliana treated with B1N1 at $0 \mathrm{dS} / \mathrm{m}(0.77), 2 \mathrm{dS} / \mathrm{m}(0.77)$, $6 \mathrm{dS} / \mathrm{m}(0.78)$ and $8 \mathrm{dS} / \mathrm{m}(0.75)$ were higher from the control $(0.72)$ but the differences were not significant. Only B1N1 at $4 \mathrm{dS} / \mathrm{m}(0.65)$ was significantly lower from the control.

\section{Effects of betaine-rich Nano fertilizer on leaf RWC of sweet corn and $A$. thaliana}

The interaction between salinity levels and betaine Nano fertilizer on leaf RWC was statistically significant in $A$. thaliana $(p<0.0005)$, but not in sweet corn $(p=0.082)$. The leaf RWC of sweet corn treated with B1N1 at $0 \mathrm{dS} / \mathrm{m}(96.33 \%), 2 \mathrm{dS} / \mathrm{m}$ (96.87\%), $4 \mathrm{dS} / \mathrm{m}(95.71 \%), 6 \mathrm{dS} / \mathrm{m}(96.70 \%)$ and 8

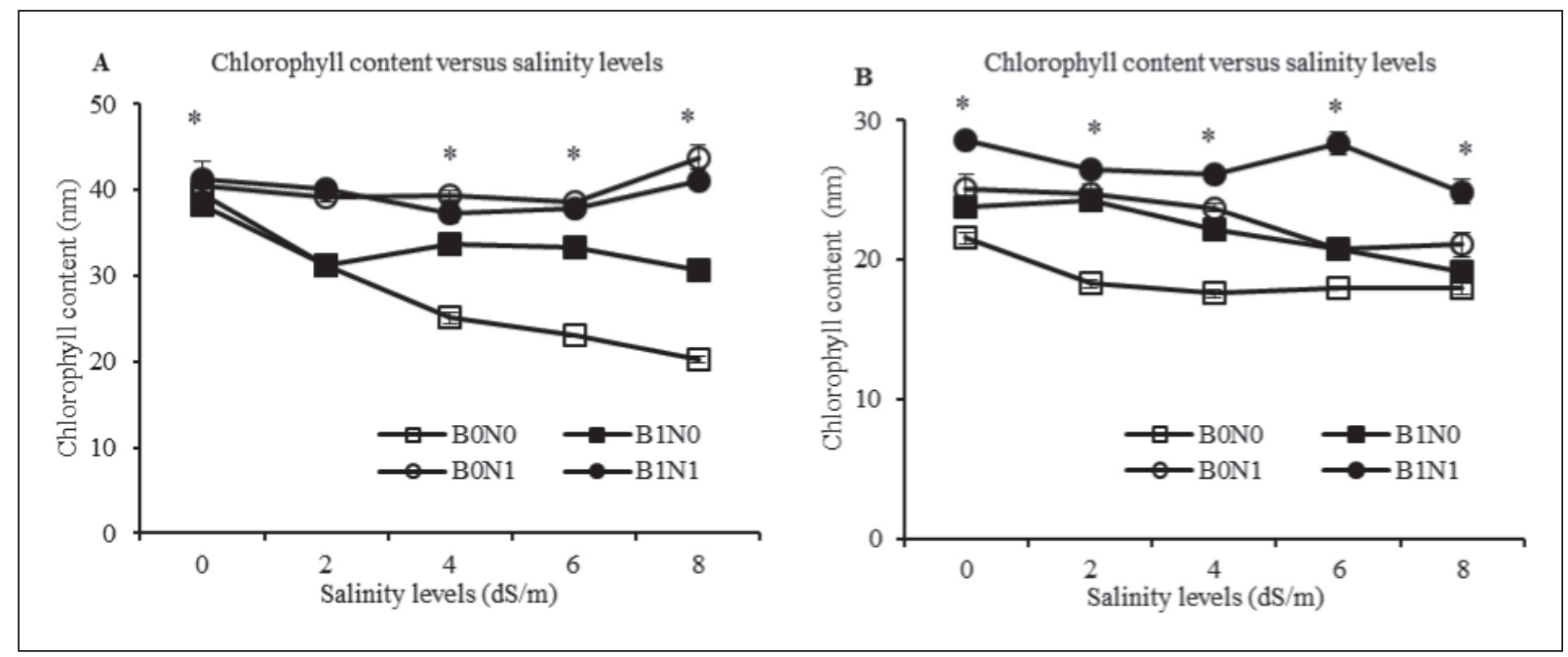

Fig. 1. Effects of different treatments of betaine-rich Nano fertilizer on chlorophyll content of sweet corn (A) and A. thaliana (B) under different salinity levels.

$\mathrm{B} 0=$ no betaine, $\mathrm{N} 0=$ no Nano fertilizer, $\mathrm{B} 1=$ with betaine and $\mathrm{N} 1=$ with Nano fertilizer. Single asterisk $*$ indicated B1N1 was significantly different from the control (B0N0) at $0 \mathrm{dS} / \mathrm{m}(p<0.05)$. 


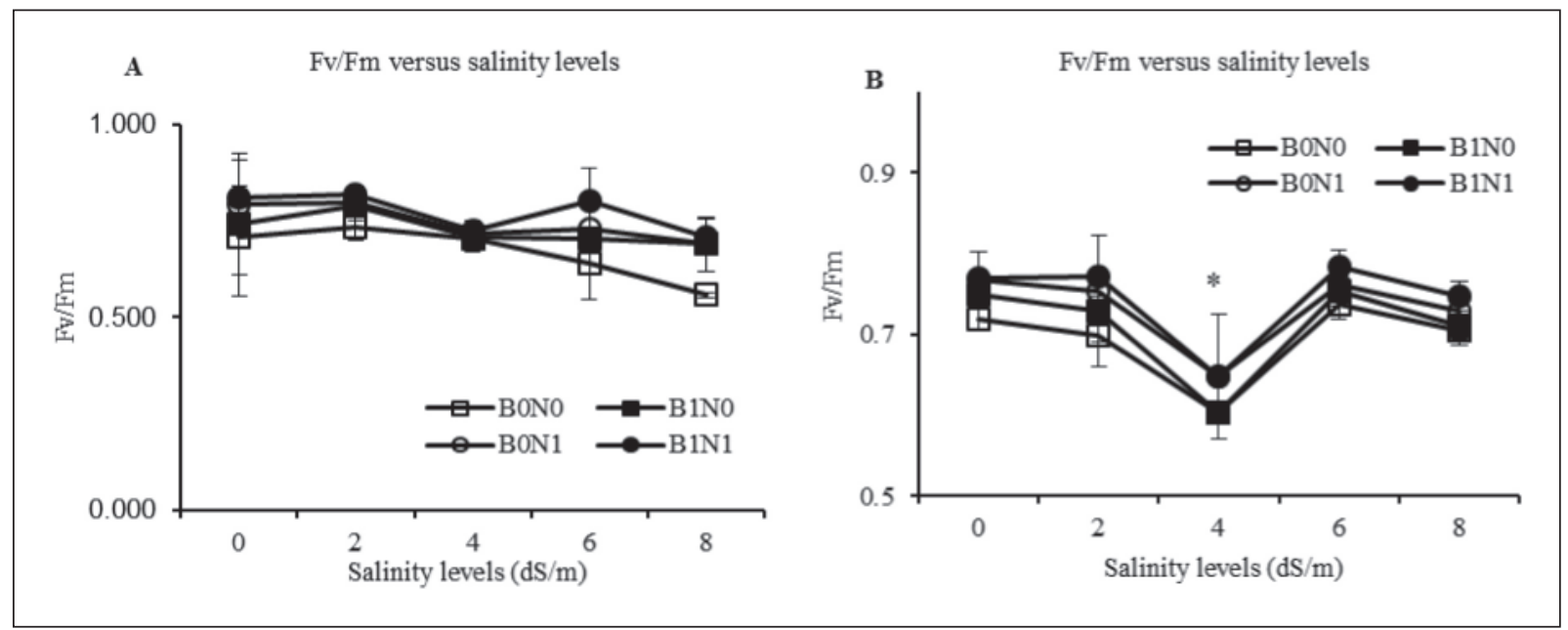

Fig. 2. Effects of different treatments of betaine-rich Nano fertilizer on chlorophyll fluorescence (Fv/Fm) of sweet corn (A) and $A$. thaliana (B) under different salinity levels.

$\mathrm{B} 0=$ no betaine, $\mathrm{N} 0=$ no Nano fertilizer, $\mathrm{B} 1=$ with betaine and $\mathrm{N} 1=$ with Nano fertilizer. Single asterisk $*$ indicated B1N1 was significantly different from the control $(\mathrm{B} 0 \mathrm{~N} 0)$ at $0 \mathrm{dS} / \mathrm{m}(p<0.05)$.
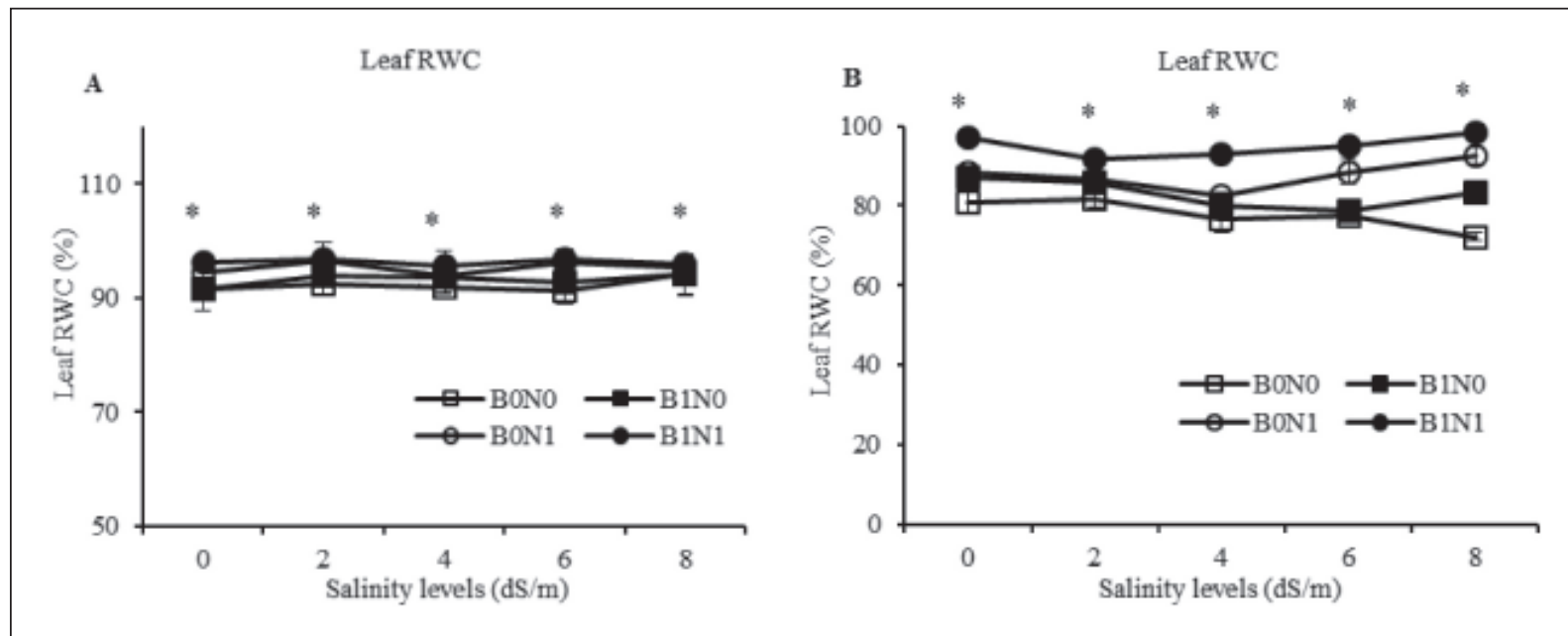

Fig. 3. Effects of different treatments of betaine-rich Nano fertilizer on leaf RWC of sweet corn (A) and A. thaliana (B) under different salinity levels.

$\mathrm{B} 0=$ no betaine, $\mathrm{N} 0=$ no Nano fertilizer, $\mathrm{B} 1=$ with betaine and $\mathrm{N} 1=$ with Nano fertilizer. Single asterisk $*$ indicated B1N1 was significantly different from the control (B0N0) at $0 \mathrm{dS} / \mathrm{m}(p<0.05)$.

$\mathrm{dS} / \mathrm{m}(95.90 \%)$ were statistically significant compared to the control (91.49\%) (Figure 3A).

The leaf RWC of $A$. thaliana treated with B1N1 was increased at $4 \mathrm{dS} / \mathrm{m}$ (93.07\%), $6 \mathrm{dS} / \mathrm{m}(95.12 \%)$ and $8 \mathrm{dS} / \mathrm{m}(98.38 \%)$ although it was dropped from $0 \mathrm{dS} / \mathrm{m}(96.97 \%)$ to $2 \mathrm{dS} / \mathrm{m}(91.50 \%)$. Also, B1N1 under all salinity levels were significantly higher from the control (80.76\%) (Figure 3B).

\section{DISCUSSION}

The decline of chlorophyll content in plants under saline conditions is a common effect of oxidative stress (Taibi et al., 2016). Ion accumulation under saline conditions repressed enzymes chlorophyllase, attributed to the suppression of chlorophyll biosynthesis (Taibi et al., 2016). The suppression of chlorophyll biosynthesis caused a decrease in chlorophyll content (Babaei et al., 2017) hence the efficiency of photosynthesis is affected (Rady et al., 2018). Depletion of $F_{V} / F_{M}$ under saline conditions also led to the reduction of chlorophyll pigment (Babaei et al., 2017). The $\mathrm{F}_{\mathrm{V}} / \mathrm{F}_{\mathrm{M}}$ was reduced in saline conditions due to inhibition of electron transport at the acceptor side of PS II (Lucini et al., 2015). Destruction of PS II consequently affects carbon dioxide $\left(\mathrm{CO}_{2}\right)$ fixation, indirectly halt the activation of Rubisco (Iqbal et al., 2015). Hence, the development and growth of cells slowed and inhibited due to low ATP production. 
Leaf RWC indicated water status in plants and vital to preserve osmotic adjustment in a plant cell to achieve optimum productivity of the photosynthesis process (Bhuiyan et al., 2016). The lowest leaf RWC value in sweet corn and $A$. thaliana were observed at 6 and $8 \mathrm{dS} / \mathrm{m}$, respectively. This relates to the incompletion of cell development due to the decrease of chlorophyll content and fluorescence $\left(\mathrm{F}_{\mathrm{V}} / \mathrm{F}_{\mathrm{M}}\right)$ under saline conditions. Furthermore, saline conditions gave an impact on water and ions absorption in the plant (Babaei et al., 2017). The attenuation of water content in the plant created osmotic stress, induces stomatal closure to maintain water balance in the plant (Ghorbani et al., 2018).

However, the application of betaine-rich Nano fertilizer through the soil and foliar application methods demonstrated a significant increment in chlorophyll content and leaf RWC under saline conditions compared to the control, meanwhile, chlorophyll fluorescence $\left(\mathrm{F}_{\mathrm{V}} / \mathrm{F}_{\mathrm{M}}\right)$ was comparable to control under saline conditions. In this paper, we showed the effects of betaine-rich Nano fertilizer in reducing the detrimental consequences of salt stress on glycophytes, Z. mays var. sacchrata, and model plant, $A$. thaliana by using different methods. Soil application methods allowed nutrients to enter plants through root hairs, lenticels, mucilage, and exudates (Farooqui et al., 2016) while foliar application easily penetrated by the leaves through stomata, hydathodes, and trichomes, later transported to all parts of the plant via phloem pathway (Sturikova et al., 2018).

Betaine and Nano fertilizer alleviated detrimental effects in a salt-stressed plant by discriminating excess salts (Kheir et al., 2019) and ROS (Wei et al., 2017). The uptake and allocation of $\mathrm{K}^{+}$by the plant was improved (Alasvandyari et al., 2017; Kheir et al., 2019), boosted non-enzymatic antioxidants and enzymatic antioxidant (Torabian et al., 2017). Consequently, promoted water holding capacity in the plant cells (Kheir et al., 2019), thus, increased turgor pressure and strength of plant cell wall (Yassen et al., 2017). The increase of RWC provided better osmotic regulation in the plant, maintained stomatal aperture which increased chlorophyll content and fluorescence $\left(\mathrm{F}_{\mathrm{V}} / \mathrm{F}_{\mathrm{M}}\right)$ (Babaei et al., 2017). Moreover, the absorption of nutrients enhanced, therefore, balanced the nutrient loss (El-Ramady et al., 2018).

\section{CONCLUSION}

Saline conditions suppressed the chlorophyll content, chlorophyll fluorescence $\left(\mathrm{F}_{\mathrm{V}} / \mathrm{F}_{\mathrm{M}}\right)$, and leaf RWC of sweet corn and A. thaliana. The present study proved that the application of betaine-rich Nano fertilizer by foliar or soil methods have significantly improved the chlorophyll content and leaf RWC in both sweet corn and A. thaliana. It is believed that betaine and Nano fertilizer ameliorates salt-affected damage by elevating endogenous antioxidant defense in plants under saline conditions. Hence, promotes the photosynthetic activity and induces plant cell to retain water. However, the effects of betaine-rich Nano fertilizer in plants may vary depending on the plant species, duration of salt stress, and repetition of treatments. Therefore, a field study is needed to examine the effects of betainerich Nano fertilizer on salt-stressed plants in further detail.

\section{ACKNOWLEDGEMENTS}

This study was funded by a research grant (UniSZA/ 2017/SRGS/02) no R0019-R002 and supported by the Faculty of Bioresources and Food Industry, Universiti Sultan Zainal Abidin (UniSZA), Terengganu, Malaysia.

\section{REFERENCES}

Alasvandyari, F., Mahdavi, B. \& Hosseini, S.M. 2017. Glycine betaine affects the antioxidant system and ion accumulation and reduces salinity-induced damage in safflower seedlings. Archives of Biological Sciences, 69(1): 139-147.

Alipour, Z.T. 2016. The effect of phosphorus and sulfur nanofertilizers on the growth and nutrition of Ocimum basilicum in response to salt stress. Journal of Chemical Health Risks, 6(2): 125-131.

Babaei, K., Seyed Sharifi, R., Pirzad, A. \& Khalilzadeh, R. 2017. Effects of bio fertilizer and nano $\mathrm{Zn}-\mathrm{Fe}$ oxide on physiological traits, antioxidant enzymes activity, and yield of wheat (Triticum aestivum L.) under salinity stress. Journal of Plant Interactions, 12(1): 381389.

Bhuiyan, M.S., Maynard, G., Raman, A., Hodgkins, D., Mitchell, D. \& Nicol, H. 2016. Salt effects on proline and glycine betaine levels and photosynthetic performance in Melilotus siculus, Tecticornia pergranulata, and Thinopyrum ponticum measured in simulated saline conditions. Functional Plant Biology, 43(3): 254-265.

Butcher, K., Wick, A.F., DeSutter, T., Chatterjee, A. \& Harmon, J. 2016. Soil salinity: A threat to global food security. Agronomy Journal, 108(6): 2189-2200. 
Chen, J., Lü, S., Zhang, Z., Zhao, X., Li, X., Ning, P. \& Liu, M. 2018. Environmentally friendly fertilizers: A review of materials used and their effects on the environment. Science of the Total Environment, 613: 829-839.

Chhipa, H. 2017. Nanofertilizers and nanopesticides for agriculture. Environmental Chemistry Letters, 15(1): 15-22.

Day, C.R. \& Kempson, S.A. 2016. Betaine chemistry, roles, and potential use in liver disease. Biochimica et Biophysica Acta (BBA)-General Subjects, 1860(6): 1098-1106.

El-Ramady, H., Abdalla, N., Alshaal, T., El-Henawy, A., Elmahrouk, M., Bayoumi, Y. \& DomokosSzabolcsy, É. 2018. Plant nano-nutrition: perspectives and challenges. In Nanotechnology, Food Security, and Water Treatment. Springer International Publishing, Switzerland. 129-161 pp.

Farooqui, A., Tabassum, H., Ahmad, A., Mabood, A., Ahmad, A. \& Ahmad, I.Z. 2016. Role of nanoparticles in growth and development of plants: A review. International Journal of Pharma and Bio Sciences, 7(4): 22-37.

Ghorbani, A., Razavi, S.M., Ghasemi Omran, V.O. \& Pirdashti, H. 2018. Piriformospora indica inoculation alleviates the adverse effect of $\mathrm{NaCl}$ stress on growth, gas exchange, and chlorophyll fluorescence in tomato (Solanum lycopersicum L.). Plant Biology, 20(4): 729-736.

Habib, S.H., Kausar, H. \& Saud, H.M. 2016. Plant growth-promoting rhizobacteria enhance salinity stress tolerance in okra through ROSscavenging enzymes. BioMed Research International, 2016: 1-10.

Hezaveh, T.A., Pourakbar, L., Rahmani, F. \& Alipour, H. 2019. Interactive effects of salinity and $\mathrm{ZnO}$ nanoparticles on physiological and molecular parameters of rapeseed (Brassica napus L.). Communications in Soil Science and Plant Analysis, 50(6): 698-715.

Iqbal, N., Nazar, R. \& Khan, N.A. 2015. Osmolytes and plants acclimation to changing environment: emerging omics technologies. 1st Ed. Springer India, India. 83-96 pp.

Joshi, R., Mangu, V.R., Bedre, R., Sanchez, L., Pilcher, W., Zandkarimi, H. \& Baisakh, N. 2015. Salt adaptation mechanisms of halophytes: improvement of salt tolerance in crop plants. In Elucidation of abiotic stress signaling in plants. Springer, New York, NY. 243-279 pp.

Kheir, A.M.S., Abouelsoud, H.M., Hafez, E.M. \& Ali, O.A.M. 2019. Integrated effect of nano-Zn, nano-Si, and drainage using crop straw-filled ditches on saline sodic soil properties and rice productivity. Arabian Journal of Geosciences, 12(15): 471.
Liang, W., Ma, X., Wan, P. \& Liu, L. 2018. Plant salt-tolerance mechanism: a review. Biochemical and Biophysical Research Communications, 495(1): 286-291.

León-Silva, S., Arrieta-Cortes, R., FernándezLuqueño, F. \& López-Valdez, F. 2018. Design and production of nanofertilizers. In Agricultural Nanobiotechnology Springer, Cham, Switzerland. 17-31 pp.

Lucini, L., Rouphael, Y., Cardarelli, M., Canaguier, R., Kumar, P. \& Colla, G. 2015. The effect of a plant-derived biostimulant on metabolic profiling and crop performance of lettuce grown under saline conditions. Scientia Horticulturae, 182: 124-133.

Machado, R. \& Serralheiro, R. 2017. Soil salinity: effect on vegetable crop growth. Management practices to prevent and mitigate soil salinization. Horticulturae, 3(2): 30.

Rady, M.O., Semida, W.M., El-Mageed, T.A.A., Hemida, K.A. \& Rady, M.M. 2018. Upregulation of antioxidative defense systems by glycine betaine foliar application in onion plants confer tolerance to salinity stress. Scientia Horticulturae, 240: 614-622.

Siyuan, S., Tong, L. \& Liu, R.H. 2018. Corn phytochemicals and their health benefits. Food Science and Human Wellness, 7(3): 185-195.

Sturikova, H., Krystofova, O., Huska, D. \& Adam, V. 2018. Zinc, zinc nanoparticles, and plants. Journal of Hazardous Materials, 349: 101-110.

Syuhada, N. \& Jahan, M.S. 2016. Glutathione functions on physiological characters to increase copper-induced corn production. Russian Agricultural Sciences, 42(1): 5-10.

Tian, F., Wang, W., Liang, C., Wang, X., Wang, G. \& Wang, W. 2017. Overaccumulation of glycine betaine makes the function of the thylakoid membrane better in wheat under salt stress. The Crop Journal, 5(1): 73-82.

Torabian, S., Zahedi, M. \& Khoshgoftar, A.H. 2017. Effects of foliar spray of nano-particles of FeSO4 on the growth and ion content of sunflower under saline condition. Journal of Plant Nutrition, 40(5): 615-623.

Wei, D., Zhang, W., Wang, C., Meng, Q., Li, G., Chen, T.H. \& Yang, X. 2017. Genetic engineering of the biosynthesis of glycinebetaine leads to alleviate salt-induced potassium efflux and enhances salt tolerance in tomato plants. Plant Science, 257: 74-83.

Yassen, A., Abdallah, E., Gaballah, M. \& Zaghloul, S. 2017. Role of Silicon dioxide nano fertilizer in mitigating salt stress on growth, yield, and chemical composition of Cucumber (Cucumis sativus L.). International Journal of Agricultural Research, 22: 130-135. 